\title{
Infrastructure Development of Road Network for Regional Development Based on Accessibility Concept
}

\author{
Heri Amalindo", Anis Saggaff \#, Joni Arliansyah",** \\ \# Civil Engineering Department, Sriwijaya University, Inderalaya South Sumatera, 30602, Indonesia \\ E-mail: joniarliansyah@yahoo.com
}

\begin{abstract}
Penukal Abab Lematang Ilir (PALI) District is a new district in South Sumatera Province, Indonesia which has been established since 2013 and has five subdistricts and 72 villages. PALI district continuously implements regional development to improve the living standard and economy of the community. Consequently, the infrastructure development of road network based on needs of improvement of accessibility and the spatial area is a precondition for economic and regional development and improvement of competitiveness of PALI district in South Sumatera Province. This research aimed to study the needs of infrastructure development of road network in PALI District regarding the economic and regional development and other sectors based on accessibility measurement. The data of existing infrastructure and regional condition and spatial area plan are activity centres, spatial patterns, and strategic area to be fundamental in determining the infrastructure development of road network for either internal or external accessibility of PALI District area. The existing condition based on the accessibility values show that several villages which are the priority of development have low accessibility so that the development of road infrastructure networks is needed. The simulation of scenarios of road network development was conducted to get the best accessibility score in order to support the plan of the existing economic and regional development. The result of the study is the plan of infrastructure development of road network of PALI District that can really support economic growth and regional development in PALI District.
\end{abstract}

Keywords - accessibility measurement; road infrastructure development; infrastructure; spatial area accessibility.

\section{INTRODUCTION}

Penukal Abab Lematang Ilir (PALI) District is a new district in South Sumatra Province having exceptionally good at agriculture, plantation, and mining sectors which are expected to develop fast from time to time. Hasan, M. [1] explained in his book the eds of infrastructure to support area development. The infrastructure construction to support the needs of the movement of people and goods continues to be carried out along with the development of the district to exploit the potential of the region optimally. Having fast regional development, PALI District is faced with challenges, particularly those related to the provision of regional transportation infrastructure.

The spatial planning has planned the points of regional development and strategic area plan embodied in the spatial plan of PALI District, where the centers of economic, cultural and other development have been mapped in the spatial plan. In spatial planning, it needs road network development as a connection of the analyzed strategic areas to the accessibility and mobility parameters. This is the main indicator needed in road network infrastructure development, particularly for a region of a new autonomy such as PALI District. The high accessibility level in one area will improve the competitiveness of that area. The connectedness and accessibility reaching centers of utility make it easy to have productive activities. Man, T. et al. [2] studied the spatial impacts of infrastructure constructions in improving accessibility in Romania. Marinos, PD [3] revealed how to elaborate spatial development to sustainable in relation. The productivity combination of each zone will positively affect the improvement of competitiveness of a region.

The development of supporting infrastructure for movement activities that accommodate the needs of movement will be directly proportional to economic activity because good accessibility in a region is the key and the prerequisite of economic development in that region. Accessibility development which one of them is with road network development must be based on accessibility analysis, development plan, and regional spatial plan. Because PALI is a new district where its infrastructure condition has not been optimal in supporting regional development, it is necessary to have a road network development plan in PALI District. The study aimed to evaluate the accessibility of the existing network and develop the alternative of road network development in supporting the regional development plan of PALI District. 


\section{A. The concept of Regional Development}

Mahi, A.K [4] studied the spatial development, the concept of regional development, among others, consists of the concept of the growth poles, the development of small towns, the development of integrated space and the development of agropolitan.

The concept of growth poles is a development aimed at economic growth with an efficiency that emphasizes the growth of new equity that is expected to be duplicated in other regions. The concept of small-town development is that of developing the center of growth in a location that can spur economic improvement geographically and attract investment in the area concerned. The concept of integrated space is a development that aims to improve economic and equity simultaneously with the relevance of activities with land use expected to occur in the production system integration and community participation so that the development is both tops down and bottom up. The concept of agropolitan is that of harmonizing the agropolitan activities whose agricultural development is with industry optimally at the location of the development area. The concept of regional development selected for PALI District is that of integrated space development (functional integration) combined with the agropolitan concept. It is since the regional characteristics and potential are focused on agricultural sectors (plantation, fishery, and agriculture food crops). The concept of regional integration development of Penukal Abab Lematang Ilir District aims to develop an integrated city system which is supported by the development of adequate transportation and infrastructure system, and the sustainable agriculture activities are developed in the rear areas of the cities.

\section{B. Area Accessibility}

Tamin Z. O. [5] points out that accessibility is a concept combining a system of geographical land use arrangement with the existing transportation network system. Jan Scheurer [6] states that indicators of regional accessibility comprise 7 categories of regional accessibility measurement as follows: 1.Spatial Measurement; 2. Contour Measurement; 3.Gravity Measurement; 4.Competition Measurement; 5.Time Span Measurement; 6.Utility Measurement; 7.Network Measurement.

In the measurement of accessibility of new autonomous regions, there will be network measurement in which calculating the degree of ease of reaching a destination location is based on an intersection between paths within the network. The formula of accessibility calculation developed by Jan Scheurer as follows

$$
\begin{aligned}
& C I=\sum_{j}^{n} c i j \\
& \text { Where: } \mathrm{CI}=\text { accessibility index } \\
& \mathrm{Cij}=\text { number of link } \\
& \mathrm{n}=\text { number of node }
\end{aligned}
$$

Accessibility evaluation of land-use and transport system has been reported [7]-[11].

\section{MATERIAL AND Method}

Methodology describes the flow of research from the beginning to the end. Fig 1 shows the research flow diagram

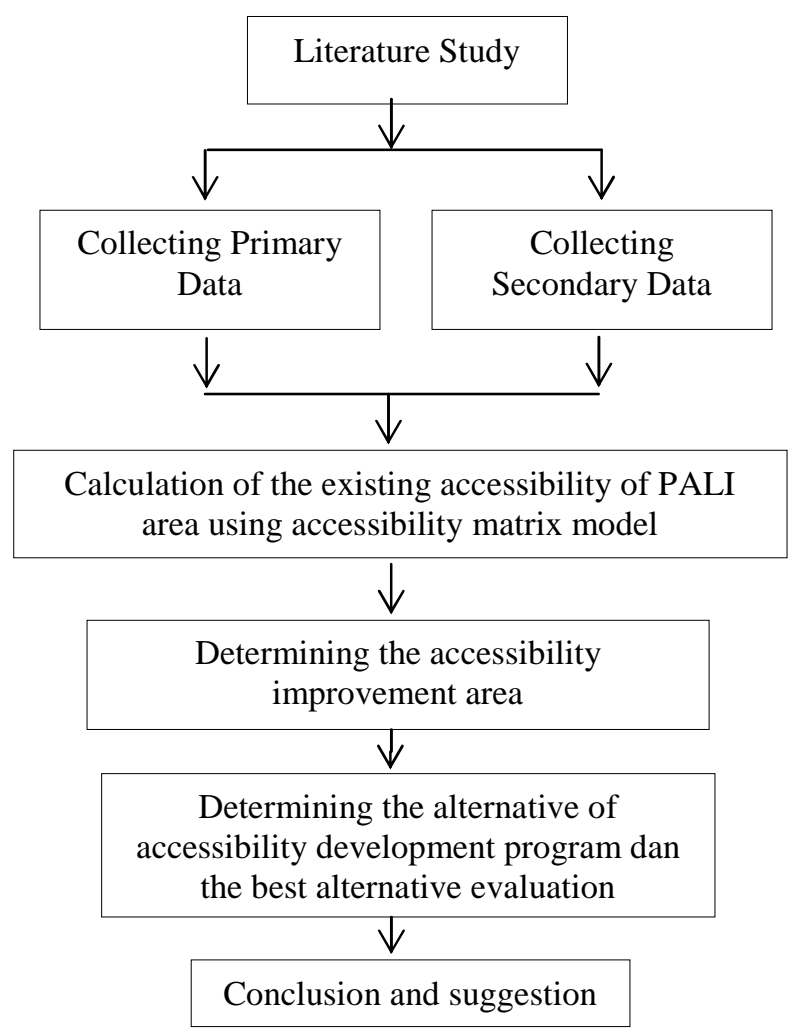

Fig. 1 Research Flow Diagram

In measuring the accessibility, the procedure was as follows:

- Identifying link and meeting point in the existing network

- Defining connectivity matrix

- Calculating accessibility matrix

The following are the phases of the calculation process of accessibility matric:

- Arrange the initial network matrix based on the road network map and name it $\mathrm{C}^{1}$ on the matrix. Specify Matrix $T=C^{2}$ and initial value $n=1$. Then check if each element on the matrix $\mathrm{T}$ has no zero value. If not, then $\mathrm{m}=1$ and directly proceed to step 5

- Calculate $\mathrm{m}=\mathrm{n}+1$ dan $\mathrm{C}^{\mathrm{m}}=\mathrm{C}^{1} \mathrm{xC}^{2}$

- Calculate $\mathrm{T}+\mathrm{C}^{\mathrm{m}}$

- Iteration is stopped when the matrix $\mathrm{T}$ has no elements of 0 value

- Calculation of accessibility value

The road network development of PALI District is carried out by:

- The existing accessibility condition for each area connected by the existing road network.

- Road network development scenario of improving regional accessibility for a plan of activity center and strategic areas.

- Selected road network development plan. 


\section{RESUlT AND DISCUSSION}

\section{A. Plan of Area Development}

Based on the spatial planning of PALI District (2016) [12], there are planned development points in several categories, namely:

- Centre of Local Activity (CLA)

- Centre of Promotion Local Activity (CPLA)

- Centre of Regional Services (CRS)

- Centre of Environment Services (CES)

CLA is a central area of major growth center area with government orientation and trade of government and industry. CPLA is a central area of subdistrict-scale trades, services, and distribution. CRS is developed to be a center of production and industries of subdistrict-scale plantation and agriculture to support the city. CES is centers of agriculture production at local-scale villages which are planned to be an urban area. Fig. 2 shows planned development areas and plan of activity center development is shown in Table 1.

TABLE I

Plan of DEVELOPMENT CENTRES OF PALI DisTRICT

\begin{tabular}{|c|c|l|l|}
\hline No & Category & \multicolumn{1}{|c|}{ Location } & \multicolumn{1}{c|}{ Allotment } \\
\hline 1 & CLA & Pendopo & Central government \\
\hline 2 & CPLA & Sungai Ibul & $\begin{array}{l}\text { Trades and local } \\
\text { transport meeting point }\end{array}$ \\
\hline 3 & CRS & Talang Akar & $\begin{array}{l}\text { Agriculture and entrance } \\
\text { and exit area }\end{array}$ \\
\hline 4 & CRS & Prabumenang & Mining and plantation \\
\hline 5 & CRS & Air Itam & Agriculture \\
\hline 6 & CRS & Perambatan & Trades and marketing \\
\hline 7 & CRS & Betung Barat & $\begin{array}{l}\text { Economic and social } \\
\text { services }\end{array}$ \\
\hline 8 & CRS & Kertadewa & $\begin{array}{l}\text { Village-scale transport } \\
\text { meeting point }\end{array}$ \\
\hline 9 & CES & $\begin{array}{l}\text { Sungai } \\
\text { Baung }\end{array}$ & $\begin{array}{l}\text { Residential and } \\
\text { agricultural centers }\end{array}$ \\
\hline 10 & CES & Simpang Tais & Mining and plantation \\
\hline 11 & CES & Modong & Entrance and exit area \\
\hline 12 & CES & Bumi Ayu & Tourism area \\
\hline
\end{tabular}

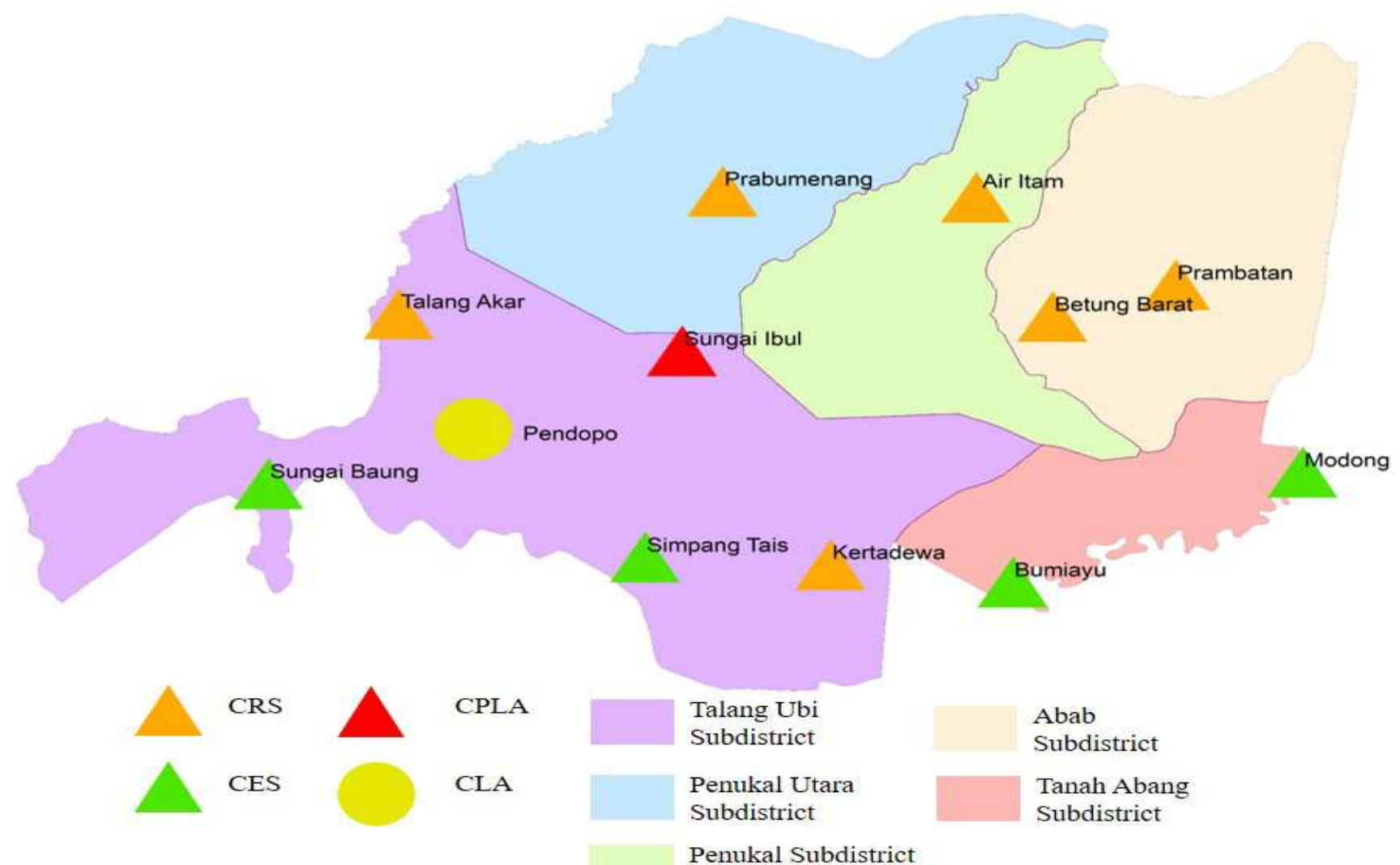

Fig. 2 Plan of Development Centre of PALI District 


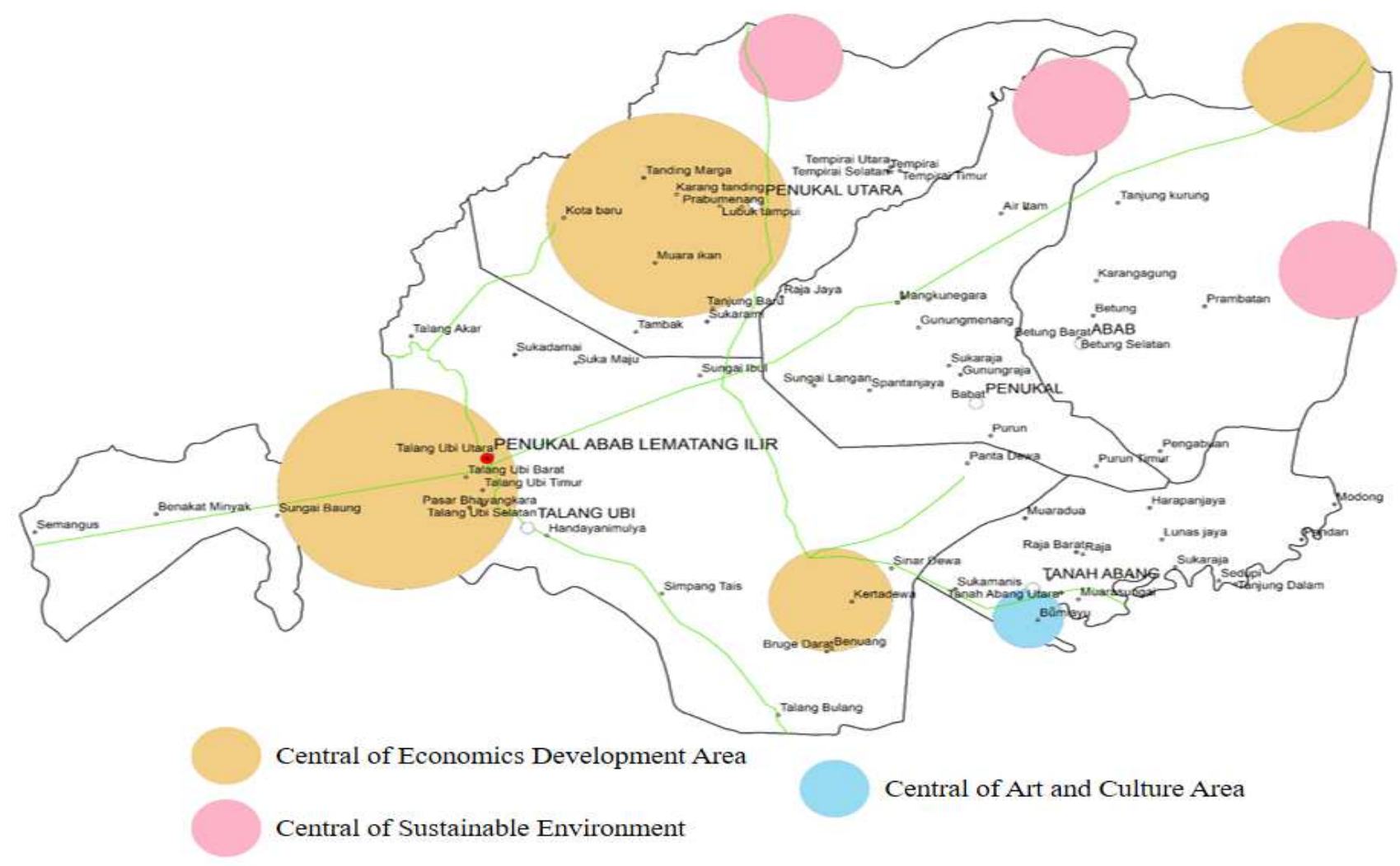

Fig. 3 Plan of Strategic Areas of PALI District

\section{B. Plan of Strategic Areas}

Strategic areas are large-scale cultivation areas/certain areas and have national and regional roles. The plan of the strategic regions is grouped into 2, namely economic strategic areas and living environmentally supportive strategic areas. Strategic areas of PALI District are shown in Figure 3. The plan of strategic area development for economic growth of PALI District is shown in Table 2.

TABLE II

PlAN OF STRATEGIC AREAS OF PALI District

\begin{tabular}{|c|l|l|}
\hline No & \multicolumn{1}{|c|}{ Types of Areas } & \multicolumn{1}{c|}{ Villages } \\
\hline 1 & Urban & Pendopo \\
\hline 2 & Agropolitan & Talang Ubi Timur \\
\hline 3 & Agropolitan & Talang Ubi Barat \\
\hline 4 & Agropolitan & Talang Ubi Selatan \\
\hline 5 & Agropolitan & Talang Akar \\
\hline 6 & Mining Port & Prambatan \\
\hline 7 & Industry & Karta Dewa \\
\hline 8 & Economic Corridor & Abab - Talang Ubi \\
\hline 9 & Economic Coridor & $\begin{array}{l}\text { Tanah Abang - Penukal } \\
\text { Utara }\end{array}$ \\
\hline
\end{tabular}

Tables 1 and 2 show that the areas needing the improvement of accessibility are, among others, as follows:

- Pendopo as a center of the urban area of industries and administration

- Sungai Ibul as a center of trade and transportation meeting point
- Entrance and exit access point of district area at villages of Talang Bulang, Kota Baru, and Sukaraja

- Bumi Ayu village which has tourism objects

- Talang Akar village which has high potential in agricultures and the entrance and exit access point of the western area

- Prambatan village which is planned to be a coal port

- Economy corridor 1 from Abab - Talang Ubi connecting Districts of PALI - Banyuasin - and Musi Rawas

- Economy corridor 2 from Tanah Abang - Penukal Utara which connects Districts of PALI - Muba Muara Enim and Prabumulih

- Sungai Baung village as a railway crossing point of Muara Enim District and Muba District

- Tanah Abang Selatan which is allotted to aquaculture development

\section{Existing Condition}

The existing network condition of PALI District is a description of the road network that accommodates the need for movement of people or goods within the area of PALI District, and then the level of accessibility on the existing network is analyzed. Fig. 4 shows the existing road network of PALI District. Table 3 shows the accessibility level of the existing network of 27 nodes and 26 connectors. 


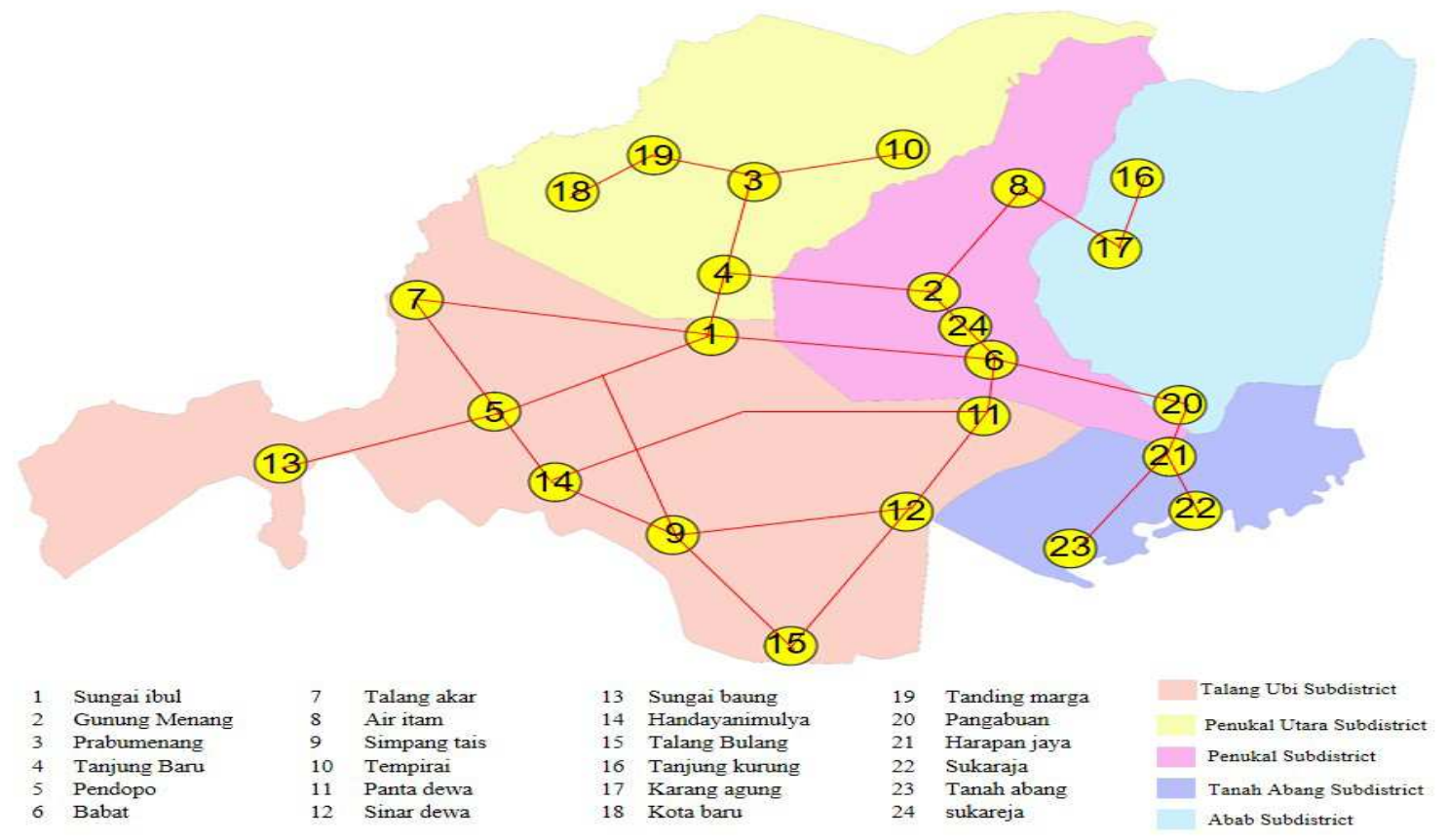

Fig. 4 Existing Condition of Road Network of PALI District

TABLE III

ANALYSIS OF ACCESSIBILITY LEVEL OF PALI DISTRICT

\begin{tabular}{|c|l|c|c|l|l|}
\hline No & Village/town & Rank & No & Village/town & Rank \\
\hline 1 & Sungai Ibul & 1 & 15 & $\begin{array}{l}\text { Handiyani } \\
\text { Mulya }\end{array}$ & 15 \\
\hline 2 & $\begin{array}{l}\text { Gunung } \\
\text { Menang }\end{array}$ & 2 & 16 & Talang Bulang & 16 \\
\hline 3 & Prabumenang & 3 & 17 & $\begin{array}{l}\text { Tanjung } \\
\text { Kurung }\end{array}$ & 17 \\
\hline 4 & $\begin{array}{l}\text { Tanjung } \\
\text { Baru }\end{array}$ & 4 & 18 & Karang Agung & 18 \\
\hline 5 & Pendopo & 5 & 19 & Air Itam Timur & 19 \\
\hline 6 & Babat & 6 & 20 & $\begin{array}{l}\text { Pangabuan } \\
\text { Timur }\end{array}$ & 20 \\
\hline 7 & Talang Akar & 7 & 21 & Kota Baru & 21 \\
\hline 8 & Air Itam & 8 & 22 & Tanding Marga & 22 \\
\hline 9 & $\begin{array}{l}\text { Simpang } \\
\text { Tais }\end{array}$ & 9 & 23 & Pangabuan & 23 \\
\hline 10 & Tempirai & 10 & 24 & Harapan Jaya & 24 \\
\hline 11 & $\begin{array}{l}\text { Karang } \\
\text { Tanding }\end{array}$ & 11 & 25 & Sukaraja & 25 \\
\hline 12 & Panta Dewa & 12 & 26 & $\begin{array}{l}\text { Tanah Abang } \\
\text { Selatan }\end{array}$ & 26 \\
\hline 13 & Sinar Dewa & 13 & 27 & Tempirai Utara & 27 \\
\hline 14 & $\begin{array}{l}\text { Sungai } \\
\text { Baung }\end{array}$ & 14 & & & \\
\hline & & & & \\
\hline
\end{tabular}

Table 3 shows that villages/towns needing accessibility improvement are Tanah Abang Selatan, Tempirai Utara, Harapan Jaya, and Sukaraja due to having accessibility ratings against lower areas. Tanah Abang Selatan village is an entrance and exit point of the District and a transit point to tourism objects of Bumi Ayu village and economy corridor of Subdistricts of Tanah Abang and Penukal Utara, while Tempirai Utara is an area of plantation and entrance and exit point of the District from the northwest. Harapan
Jaya village has agricultural cultivation whereas Sukareja village is located on the border between PALI and Prabumulih City accessible through Harapan Jaya village. Also, other areas needing accessibility improvement are those of Tempirai Selatan, Air Itam, and Betung, the three of which are not connected as the supports of fishery and plantation activities of these three villages.

\section{Road Network Development}

Based on the spatial of PALI District [12]. The plan of road network development is divided into 2 scenarios as follows:

- Primary collector road development

- Development system of the transport infrastructure network

\section{E. Central Activity Development}

The scenario of district class primary collector road development is a development plan aimed to support the economic movement activities of people and goods at the villages connected by planned roads. Scenario 1 is described as follows:

- Talang Akar Village-Tempirai Selatan Village; this road is a crossing line of Districts of Muara Enim PALI - Musi Banyuasin

- Tempirai Selatan Village - Air Itam Village; both villages have plantation, fishery, and mining potential

- Air Itam Village -Betung Selatan Village; both villages have plantation, fishery, and mining potential

- Betung Selatan Village - Kerta Dewa Village; Kerta Dewa Village is a large industrial area and Betung Selatan Village is a plantation area

- Kerta Dewa Village - Talang Bulang Village; a connector of a large industrial area and an entrance and exit line of the District

- Tempirai Selatan Village -Kerta Dewa Village; a connector of plantation and industry areas 


\section{F. Land Transport Infrastructure Network System}

- This second development scenario is developed to connect the activity centres and accommodate the need for movement of people or goods within the district, movements either from within to outside the district, or from outside into the district, accelerate the development of economic corridors and facilitate product transactions from each land use in Penukal Abab Lematang Ilir District. The second scenario is described as follows:

- A connection of Spantan Jaya Village and Spanta Dewa Village that will connect the production and provincial roads and traffic division road of the economy corridor

- The road construction connecting Gunung Menang and Betung Village which is disconnected and has no access

- A connection of villages of Tempirai Utara - Tempirai Lubuk Tampui - Muara Ikan and Tambak which will connect fishery products of PALI District

- The construction of the connecting road of areas of Talang Ubi Subdistrict and Tanah Abang is a betweensubdistrict connecting road of villages of Sinar Dewa and Suka Manis

- The construction of connecting road of areas of Subdistricts of Tanah Abang and Penukal is a between- subdistrict connecting road of villages of Sukamanis and Purun

- The construction of connecting road of areas of Subdistricts of Penukal and Penukal Utara is a betweensubdistrict connecting road of villages of Purun and Sukarami

- The construction of connecting road of areas of Subdistricts of Penukal Utara and Talang Ubi is a between-subdistrict connecting road of Sukarami Subdistrict and Sukamaju village

- The construction of the outer ring road in the territory of PALI District on villages of Modong, Sinar Dewa, Talang Bulang, Talang Ubi Timur, Sungai Baung, Talang Akar, Tanding Marga, Tempirai Utara, Tanjung Kurung, Karang Agung

- The construction of new roads to tourism access of Bumi Ayu village which has great tourism objects and potential

The two developed scenarios to improve regional accessibility and locations or strategic areas are shown in Figures 5 and 6 representing the development scenarios 1 and 2. The result of the analysis of the accessibility level of each scenario is shown in Table 4.

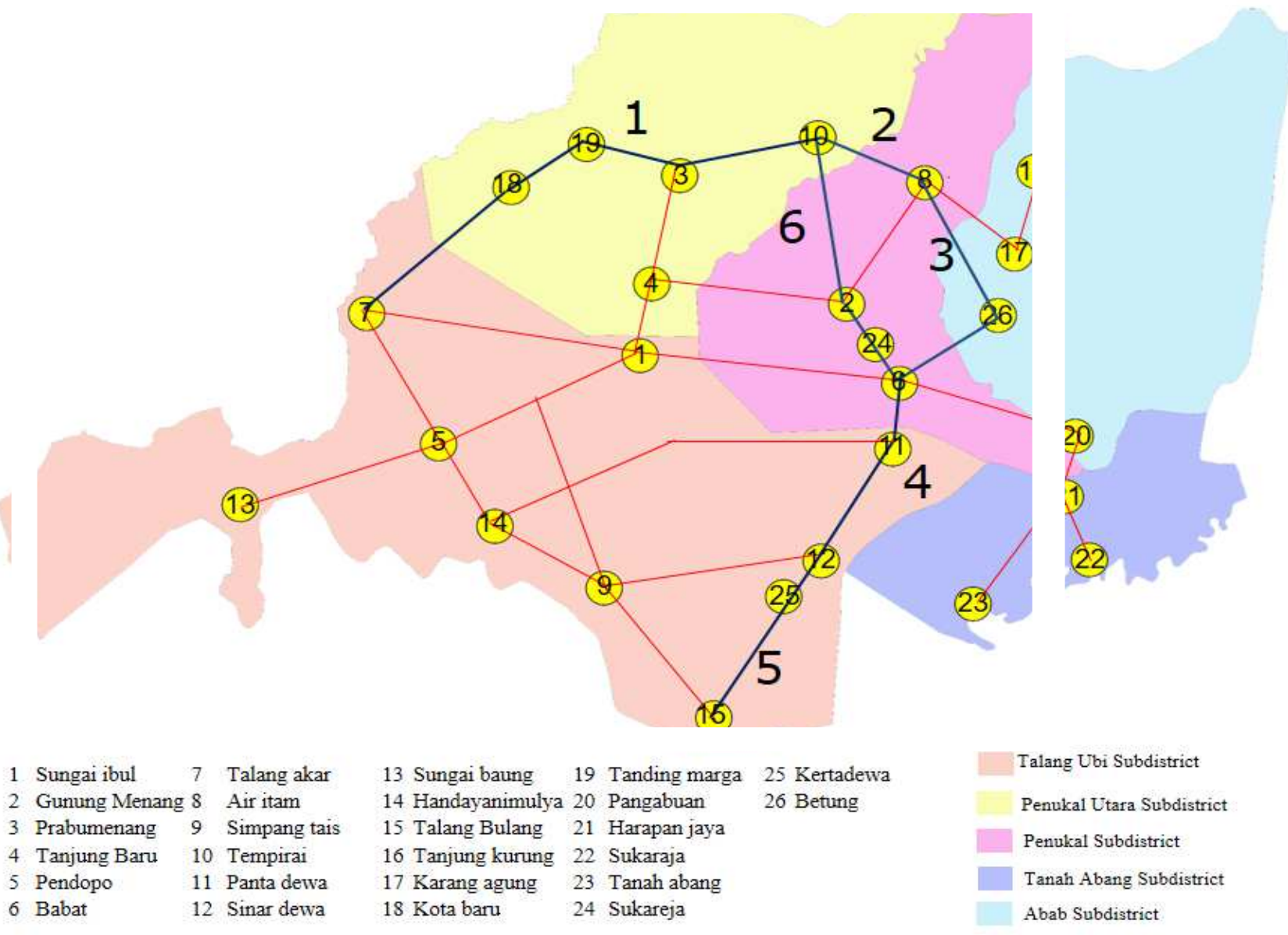

Fig. 5 Existing Condition and Development of Scenario 1 


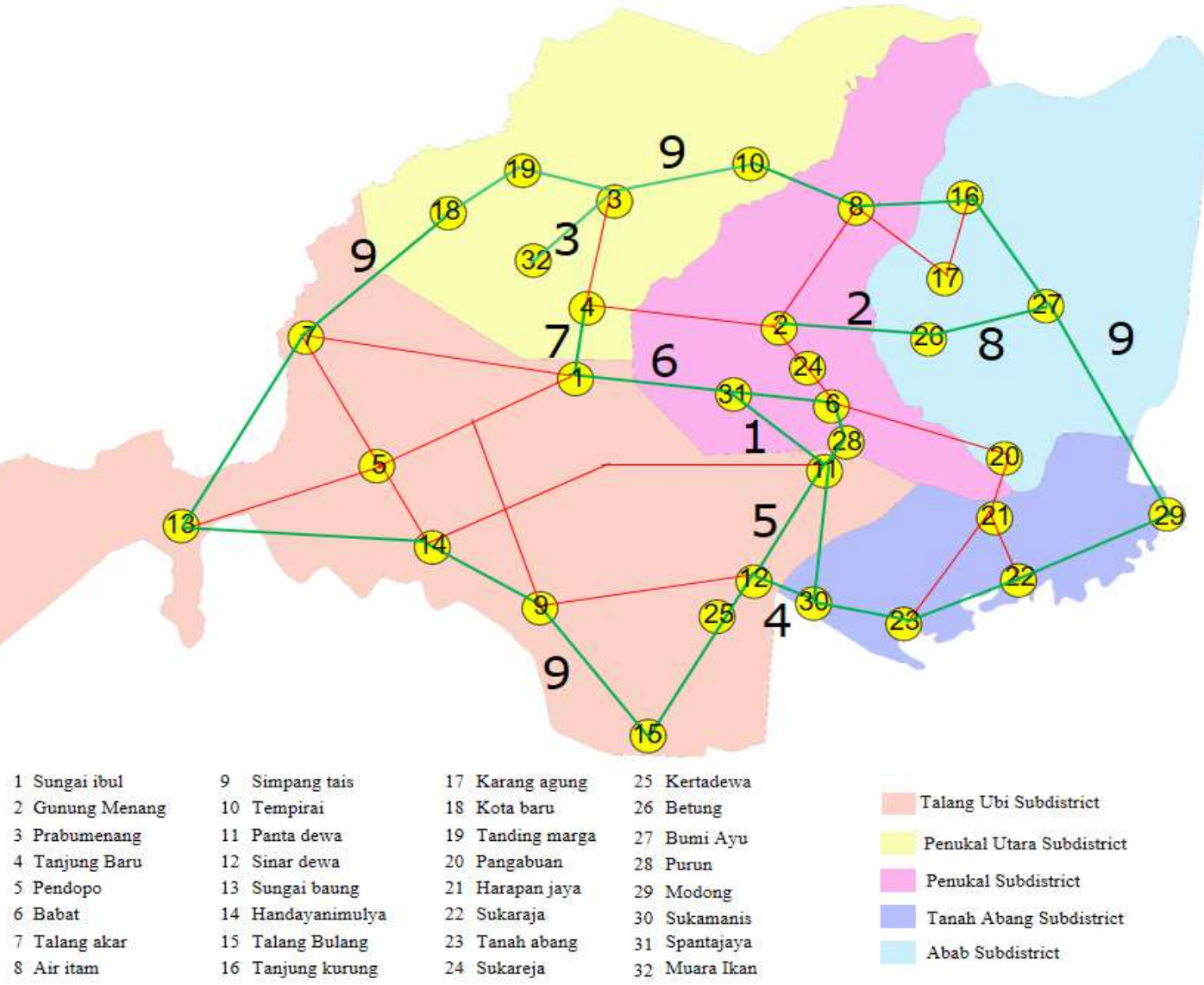

Fig. 6 Existing condition and development of scenario 2

TABLE IV

DIFRENCES RESUlt BETWEEN EXISTING AND EACH SCENARIO

\begin{tabular}{|c|c|c|c|c|c|c|c|c|c|}
\hline $\mathrm{NO}$ & City/village & existing & SC 1 & $\mathrm{SC} 2$ & NO & City/village & existing & SC 1 & $\mathrm{SC} 2$ \\
\hline 1 & Sungai Ibul & 1 & 1 & 2 & 20 & Pangabuan Timur & 20 & 21 & 19 \\
\hline 2 & Gunung Menang & 2 & 3 & 4 & 21 & Kota Baru & 21 & 23 & 20 \\
\hline 3 & Prabumenang & 3 & 4 & 5 & 22 & Tanding Marga & 22 & 22 & 22 \\
\hline 4 & Tanjung Baru & 4 & 5 & 3 & 23 & Pangabuan & 23 & 20 & 23 \\
\hline 5 & Pendopo & 5 & 4 & 1 & 24 & Harapan Jaya & 24 & 24 & 25 \\
\hline 6 & Babat & 6 & 12 & 10 & 25 & Sukaraja & 25 & 28 & 24 \\
\hline 7 & Talang Akar & 7 & 7 & 7 & 26 & Tanah Abang Selatan & 26 & 26 & 29 \\
\hline 8 & Air Itam & 8 & 8 & 6 & 27 & Tempirai Utara & 27 & 27 & 26 \\
\hline 9 & Simpang Tais & 9 & 6 & 9 & 28 & Bumi Ayu & - & 30 & 27 \\
\hline 10 & Tempirai & 10 & 9 & 8 & 29 & Kerta Dewa & - & 29 & 21 \\
\hline 11 & Karang Tanding & 11 & 14 & 12 & 30 & Spanta Jaya & - & 34 & 31 \\
\hline 12 & Panta Dewa & 12 & 10 & 11 & 31 & Betung & - & 28 & 32 \\
\hline 13 & Sinar Dewa & 13 & 11 & 13 & 32 & Lubuk Tampui & - & 33 & 30 \\
\hline 14 & Sungai Baung & 14 & 13 & 10 & 33 & Muara Ikan & - & 32 & 34 \\
\hline 15 & Handiyanimulya & 15 & 12 & 14 & 34 & Tambak & - & 31 & 36 \\
\hline 16 & Talang Bulang & 16 & 17 & 16 & 35 & Sukamanis & - & 37 & 33 \\
\hline 17 & Tanjung Kurung & 17 & 15 & 15 & 36 & Purun & - & 38 & 35 \\
\hline 18 & Karang Agung & 18 & 16 & 18 & 37 & Sukarami & - & 36 & 38 \\
\hline 19 & Air Itam Timur & 19 & 19 & 17 & 38 & Sukamaju & - & 35 & 37 \\
\hline
\end{tabular}


The above Table 4 shows that the result of the accessibility improvement of scenario 2 area is better than that of scenario 1. Pendopo becomes level 1 as the capital city of the District; Air Itam village is number 6 as an area of plantation and mining, Tempirai village is number 8 with its plantation potential, Talang Bulang village remains number 16 as entrance access of the District, Bumi Ayu village having tourism potential is number 27, Kartadewa is number 21 as an industrial area, and Spanta Jaya village as an economic corridor crossing.

\section{CONCLUSION}

The existing condition shows that the development of the primary regions of activity centers needs accessibility improvement of villages such as Tanah Abang Selatan, Tempirai Utara, Harapan Jaya, Sukareja. The scenario of area development 2 using an area accessibility level is expected to be able to improve economic and regional development by performing: Connecting villages of Spantan Jaya and Panta Dewa; Construction of road connecting villages of Gunung Menang and Betung; Connecting villages of Tempirai Utara - Tempirai Lubuk Tampui Muara Ikan and Tambak; Construction of road connecting Subdistricts of Talang Ubi and Tanah Abang; Construction of road connecting Subdistricts of Tanah Abang and Penukal; Construction of road connecting Subdistricts of Penukal and Penukal Utara; Construction of road connecting Subdistricts of Penukal Utara and Talang Ubi; Construction of ring road within the territory of PALI District; Construction of new road to tourism access of Bumi Ayu.

\section{REFERENCES}

[1] Mahi, A. K., 2016. "Development Area Theory and Application", Kencana, Jakarta

[2] Man, T., Rusu, R., Moldovan, C., Marcel, I., Moldovan, NS., Harangus, I. 2015. "Spatial Impact Of The Road Infrastructure Development In Romania. AN Accessibility Approach. Romanian Review of Regional Studies", XI

[3] Tamin, O. Z. 2006. "Perencanaan dan Permodelan Transportasi", ITB, Bandung

[4] Jan, S., Curtis, C. 2007. "Accessibility Measures Overview and Practical Application".

[5] PALI district Government. "Spatial Planning of PALI District". 2016

[6] Hasan, M. 2015 "Developed an area by Spatial Planning". ANDI. Yogyakarta

[7] Marinos, P.D "Sustainable Development and Spatial Planning some consideration arising from the Greek Case. (Nodregio, Nordic Centre of Spatial Development and OTB Research Institute, Delft University of Technology, 2012) ISSN 1650-9544

[8] Yatskiv, I., Budilovich, E., "Evaluating Riga Transport System Accessibility 16thConference on Reliability and Statistics in Transportation and Communication. Riga, Latvia. 2016.

[9] Alit, P. S, "Accessibility to Public Transport Service (Case Study of Tabanan Region, Bali-Indonesia). MATEC Web of Conference 58, 02002, 2016.

[10] Koike. A., Okumura, R, "Transportation Investment and Productivity Analysis of a Japanese Case Study. MATEC Web of Conference 103, 09016, 2017.

[11] Zhang. K. G, BA. T. M, Meng. L. H, "Accessibility Research of Highway Network System in Henan Province" MATEC Web of Conference 63, 04003, 2016.

[12] Geurs. T. K, Wee. V. B, "Accessibility Evaluation of Land-use and Transport Strategies: review and research direction." Journal of Transport Geography 12 Volume 127-140. 2004. 